\title{
Renal involvement in canine leishmaniasis: a morphological and immunohistochemical study
}

[Envolvimento renal na leishmaniose canina: estudo morfológico e imunoistoquímico]

\author{
M.J.V. Soares, J.R.E. Moraes*, F.R. Moraes \\ Faculdade de Ciências Agrárias e Veterinárias - UNESP \\ Via de Acesso Prof. Paulo Donatto Castellane, s/n \\ 14884-900 - Jaboticabal, SP
}

\begin{abstract}
IgG and IgM deposits in kidneys of dogs with visceral leishmaniasis (VL) were studied in 25 symptomatic dogs (case) and 15 asymptomatic dogs (control) by an immunohistochemical method. All tested dogs were positive for VL by polymerase chain reaction, enzyme-linked immunosorbent assay, and indirect immunofluorescence test. Kidney fragments were submitted to immunohistochemical reaction. Many morphological patterns of distribution of subendothelial granules were identified for IgG and IgM in glomerular capillaries: global, segmental, diffuse, or focal. Intensity of immunohistochemical reaction to IgG was not significantly different when comparing the symptomatic and the asymptomatic animal groups by Fisher's exact test. IgM reactions were significantly different between groups $(\mathrm{P}<0.01)$. Deposits of IgM on mesangial cells and in inflammatory interstitial infiltrate were rarely seen, although IgG reactions were frequent at these sites. This study concluded that immunohistochemical reactions for IgM were more intense than those observed for $\mathrm{IgG}$ in canine $\mathrm{VL}$, and these reactions were characterized by distribution of subendothelial granules in glomerular capillaries.
\end{abstract}

Keywords: dog, Leishmania, kidneys, glomerulonephritis, immunoglobulins

\section{RESUMO}

Caracterizou-se a deposição de IgG e IgM em rins de cães com leishmaniose visceral (LV) pelo uso da técnica imunoistoquímica. Foram estudados rins de 25 cães sintomáticos (caso) e de 15 cães assintomáticos (controle). Todos os animais foram positivos para leishmaniose pela reação em cadeia da polimerase, pelo ELISA e pela imunofluorescência indireta. Fragmentos renais foram submetidos à reação imunoistoquímica. Diversos padrões morfológicos de distribuição de grânulos subendoteliais de IgG e IgM foram identificados nos capilares glomerulares: global, segmentar, difuso ou focal. A intensidade da reação imunoistoquímica da IgG, medida pelo teste exato de Fisher não diferiu entre os grupos sintomáticos e assintomáticos e a intensidade de reação da IgM foi diferente entre os grupos $(P<0,01)$. Depósitos de IgM nas células mesangiais e no infiltrado inflamatório raramente foram visualizados, no entanto as reações $\operatorname{Ig} G$ foram freqüentemente visualizadas nesses locais. Concluiu-se que as reações de IgM foram mais intensas que as reações de IgG na $L V$ canina e caracterizam-se pela distribuição de grânulos subendoteliais nos capilares glomerulares.

Palavras-chave: cão, Leishmania, rins, glomerulonefrite, imunoglobulinas

\section{INTRODUCTION}

Glomerulonephritis is characterized by immunecomplex deposition on glomerular capillary walls. These immune complexes cause proliferation of glomerular cells and thickening of capillary walls, morphologically identified as hyalinization and glomerular sclerosis. These irreversible lesions to the glomeruli incapacitate the nephrons and, with the progression of the

Recebido em 2 de setembro de 2008

Aceito em 11 de maio de 2009

* Autor para correspondência (corresponding author)

E-mail: jrmoraes@fcav.unesp.br 
disease, glomerular filtration can be reduced, resulting in azotemia and renal failure (Grauer, 1992).

In naturally acquired canine leishmaniasis infections, involvement of the kidneys is frequently observed, with characteristic tubular and interstitial lesions of glomeruli which are immunologically mediated (Poli et al., 1991).

Soluble circulating antigen-antibody complexes can be deposited in the glomerulus when there is an excess of antigen, or when molecules of antigens and antibodies are present in equal concentration in the plasma (Grauer, 1992). In infectious diseases, immune complexes have a limited capability of penetrating the basement membrane. However, in leishmaniasis, there is intense parasite destruction, which liberates antigens. Consequently, immune complexes are formed which circulate and easily penetrate the membrane, increasing subepithelial deposit (De Brito et al., 1975).

In a study of 34 dogs naturally infected by Leishmania infantum, immunohistochemical findings revealed granular deposits of IgG, IgM, and $\mathrm{C}_{3}$ in the mesangium as well as on the glomerular capillary walls (Poli et al., 1991). Granular deposits of $\mathrm{IgG}$ in the glomeruli (basal lamina of the capillaries and mesangium), in blood vessels, and in some tubules were identified, using an immunofluorescence technique in golden hamsters (Mesocricetus auratus) infected with Leishmania donovani (Agu et al., 1981).

The peroxidase-antiperoxidase (PAP) technique used to study nephropathies in dogs with leishmaniasis showed deposition of $\operatorname{IgG}, \operatorname{IgM}$, and $\operatorname{IgA}$ in the subendothelium and mesangial matrix (Nieto et al., 1992).

Immunohistochemical assay of kidneys from 26 dogs naturally infected by Leishmania chagasi detected $\operatorname{IgM}$ in all cases, and always more intensely than IgG. The immunoglobulin deposits were granular and were located on the glomerular capillary walls more than in the mesangium, for $\operatorname{IgG}$ as well as for $\operatorname{IgM}$. The distribution of these in the glomerulus was irregular, sometimes focal or diffuse, sometimes global or focal segmental (Costa et al., 2003).
The mechanism of interstitial nephritis in visceral leishmaniasis (VL) is not yet well understood. The finding of interstitial deposits of immunoglobulins and complement shown in the immunofluorescence assay in one of 50 patients of a study, supports the theory of an immunological mechanism related to parasitic infection. Considering these aspects, interstitial nephritis as well as glomerulonephritis could be the result of immunologically mediated damage (Dutra et al., 1985).

The objective of the present study was to characterize IgG and IgM deposit in kidneys of symptomatic and asymptomatic dogs with VL by using an immunohistochemical method.

\section{MATERIALS AND METHODS}

This study was carried out using kidneys tissues removed after euthanasia and necropsy from dogs with naturally acquired leishmaniasis, (approved by CEBEA (ethics and animal welfare committee), process 006237), from the city of Teresina, PI. All the dogs were tested by polymerase chain reaction (PCR), enzyme-linked immunosorbent assay (ELISA), and indirect immunofluorescence (IFI) test. A total of 40 dogs were randomly selected, all positive for visceral leishmaniasis, and were distributed into two groups The case group was composed of 25 dogs of both genders, different breeds and ages, all positive for visceral leishmaniasis and presenting clinical manifestation of disease. The control group was composed of 15 dogs, of both genders, different breeds and ages, all positive for visceral leishmaniasis although not presenting any clinical manifestation of the disease upon physical examination.

Immunohistochemistry was used for $\operatorname{IgG}$ and IgM assay. A qualitative analysis was done according to deposits marking on inflammatory infiltrate and distribution of granular deposits in glomeruli: global, segmental, diffuse, or focal. A semi-quantitative assessment classified the intensity rate of reactions in weak, moderate, or strong. All of the elements of the reaction were used as negative controls, with the exception of the primary antibody, which was substituted by phosphate buffered saline, $\mathrm{pH} 7.2$ (PBS).

Protocol was the following: paraffin-embedded tissue sections were dewaxed with xylene and 
rehydrated in decreasing concentrations of ethylic alcohol. Afterwards, the blocking of endogenous peroxidase was done by immersion in a $6 \%$ hydrogen peroxide solution diluted in methanol. For antigen retrieval, the slides were then incubated in a Dako ${ }^{\circledR}$ target retrieval ${ }^{1}, \mathrm{pH}$ 6.10 , at $96^{\circ} \mathrm{C}$ for 40 minutes. Blocking of nonspecific reactions was done with normal rabbit serum for 20 minutes, at room temperature. Goat anti-dog IgG (1:100 dilution) ${ }^{2}$ or goat anti-dog IgM (1:200 dilution) antibodies were then added. The slides were then incubated in a moist chamber at $4^{\circ} \mathrm{C}$ overnight. A biotinylated antibody rabbit anti-goat $\operatorname{IgG}(\mathrm{H}+$ $\mathrm{L})^{2}$ was then added and the slides were incubated for 45 minutes at room temperature followed by addition of the streptavidin-peroxidase ${ }^{2}$ and incubation for 30 minutes, also at room temperature. The reaction was revealed by addition of a 3,3 diaminobenzidin substrate. Afterwards, the histological sections were stained with Harry's haematoxylin, de-hydrated with ethylic alcohol in increasing concentrations, clarified by xylene, and mounted with Entellan $\left.^{\circledR}\right)^{3}$ for examination by light microscopy.

The case (symptomatic) and the control (asymptomatic) groups were compared by Fisher's Exact Test for semi-quantitative variables. The analysis was done using the SAS program/1997.

\section{RESULTS}

Immunohistochemical reactions for $\operatorname{IgG}$ and $\operatorname{IgM}$ in histological kidney sections showed subendothelial deposits of different intensities in glomerular capillaries, classified as weak, moderate, and strong. The distribution of the subendothelial granules in the glomeruli presented different distribution patterns for IgG as well as for IgM: global, segmental, diffuse, or focal. The IgM reactions were frequently more intense and prevailed in the form of subendothelial granules in the glomeruli. In these reactions, deposits on mesangial cells and in interstitial inflammatory infiltrates were rare (Fig. 1, 2 and 3). IgG reactions, also in the form of subendothelial granules, were less intense when compared to those of IgM. Mesangial cells

${ }^{1}$ Dako-Denmark

${ }^{2}$ KPL $®$ Gaithersburg, USA.

${ }^{3}$ Merck-Darmstadt, Germany. with deposits markings in cytoplasm were the most common finding. Inflammatory infiltrates were frequently marked with IgG in these kidney sections (Fig. 4, 5 and 6).

The statistical analysis of the results of the IgG immunohistochemical reactions did not identify significant difference $(\mathrm{P}=1)$ between the symptomatic and the asymptomatic groups at $1 \%$ probability (Table 1). The IgM immunohistochemical reactions showed significant difference $(\mathrm{P}=0.0136)$, as to intensity of reaction in symptomatic and asymptomatic groups.

Using the same statistical test to evaluate the intensity of $\operatorname{IgG}$ and $\operatorname{IgM}$ reaction in the symptomatic group, the test showed significant difference $(\mathrm{P}=0.0038)$. In the symptomatic group, the value of $\mathrm{P}$ was 0.0044 for the comparison of $\mathrm{IgG}$ and $\mathrm{IgM}$ reactions, so that the difference was significant at $1 \%$.

\section{DISCUSSION}

Of all mechanisms that lead to development of progressive glomerulopathies, those of immunologic nature are of the most importance. These mechanisms involve many processes that have in common the deposition of humoral immune response elements, mainly immunoglobulins and components of the complement system, on glomerular walls and/or mesangial matrix (Zatz and Fujihara, 1999).

Circulating antigen-antibody complexes can be deposited in glomeruli when there is an excess of antigens or when the antigen and antibody molecules are present in similar concentrations in the plasma (Grauer, 1992).

Kinetic studies of renal lesions in hamsters infected with $L$. donovani showed that excretion of intact $\operatorname{IgG}$ in urine causes decrease of its concentration in serum. The cause of this would be, without doubt, the glomerulonephritis detected seven days after infection. These results suggest that the glomerulonephritis responsible for abnormal filtration would be initiated or induced by a type III hyper sensibility. The lesions were more pronounced from three to four weeks (Sartori et al., 1987). 


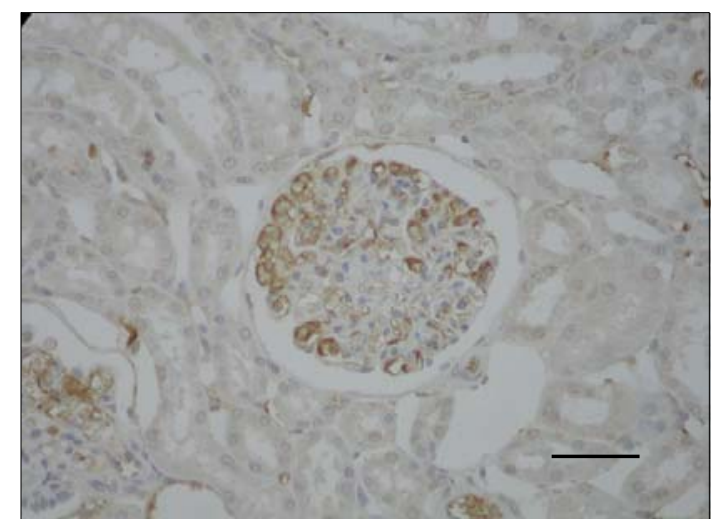

Figure 1. Immunohistochemical reaction in kidneys of dogs with visceral leishmaniasis. Presence of $\operatorname{IgM}$ subendothelial deposits in glomerular capillaries of strong intensity in a symptomatic dog. ABC. Bar $1.5 \mu \mathrm{m}$.

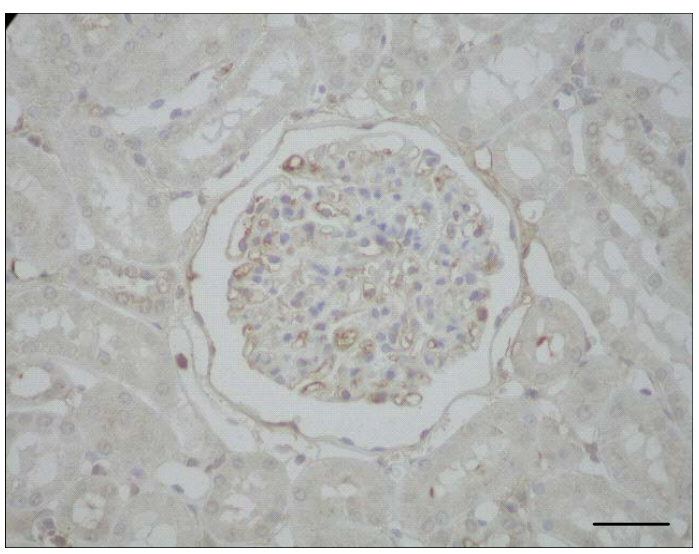

Figure 2. Immunohistochemical reaction in kidneys of dogs with visceral leishmaniasis. IgM deposits of weak intensity in an asymptomatic dog. ABC. Bar $1.5 \mu \mathrm{m}$.

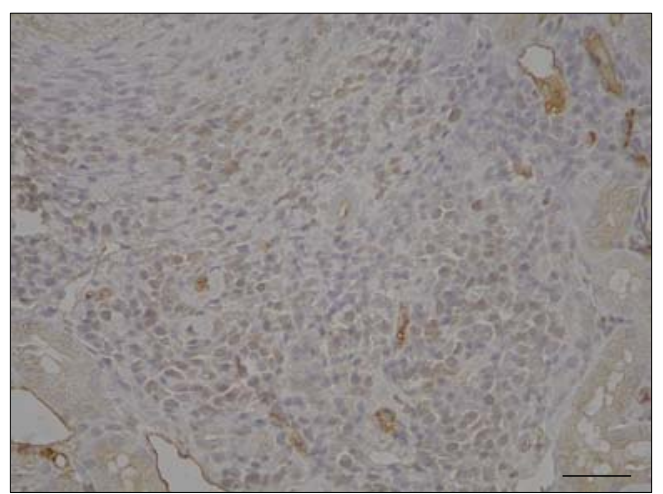

Figure 3. Immunohistochemical reaction in kidneys of dogs with visceral leishmaniasis. IgM deposits in cytoplasm of cells from mononuclearcell inflammatory infiltrate. ABC. Bar $1.5 \mu \mathrm{m}$.

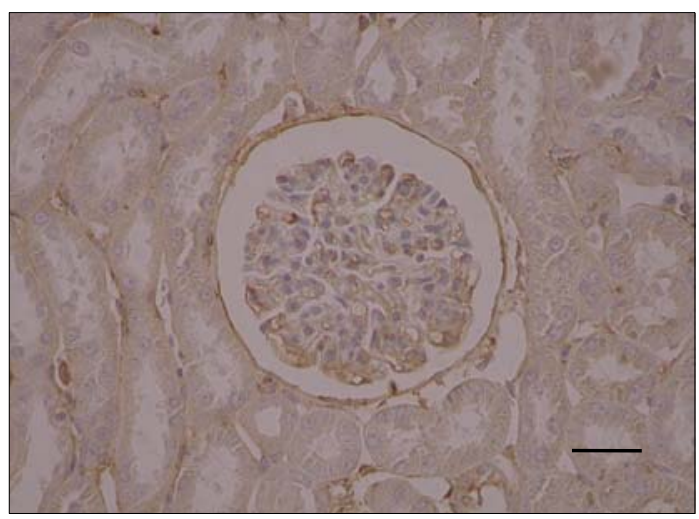

Figure 4. Immunohistochemical reaction in kidneys of dogs with visceral leishmaniasis. IgG deposits of strong intensity in a symptomatic

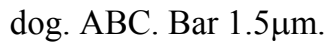

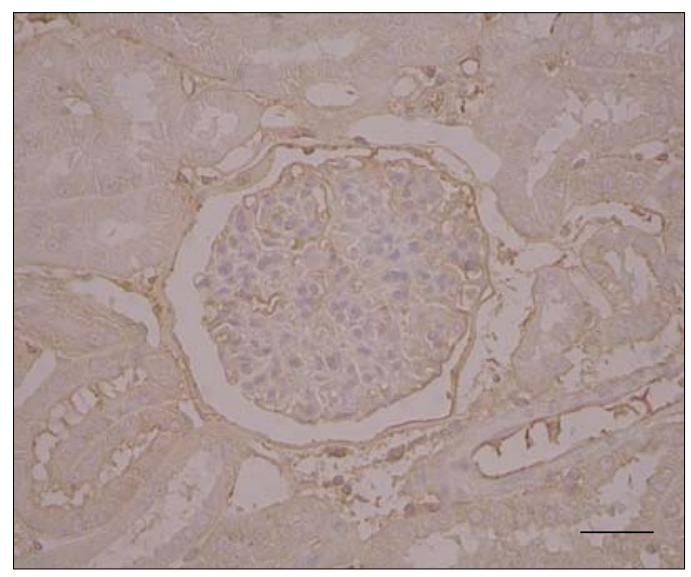

Figure 5. Immunohistochemical reaction in kidneys of dogs with visceral leishmaniasis. IgG deposits of weak intensity in an asymptomatic dog. ABC. Bar $1.5 \mu \mathrm{m}$.

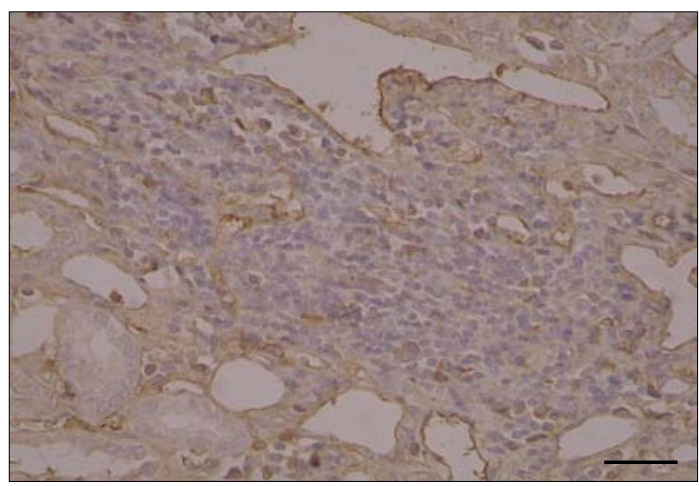

Figure 6. Immunohistochemical reaction in kidneys of dogs with visceral leishmaniasis. IgG deposits in cytoplasm of cells from mononuclear inflammatory infiltrate. ABC. Bar 1.5 $\mu \mathrm{m}$. 
Table 1. Interpretation of renal immunohistochemical assay of symptomatic and asymptomatic dogs positive for visceral leishmaniasis, from the city of Teresina-PI

\begin{tabular}{clrccc} 
& Intensity of & \multicolumn{2}{c}{ Symptomatic dogs } & \multicolumn{2}{c}{ Asymptomatic dogs } \\
& reaction & $\mathrm{n}$ & $\%$ & $\mathrm{n}$ & $\%$ \\
\hline \multirow{3}{*}{ IgG } & Weak & 20 & 80 & 11 & 73.33 \\
& Moderate & 4 & 16 & 3 & 20.00 \\
& Strong & 1 & 4 & 1 & 6.67 \\
& & & & & \\
\multirow{3}{*}{ IgM } & Weak & 10 & 40 & 2 & 13.33 \\
& Moderate & 5 & 20 & 10 & 66.67 \\
& Strong & 10 & 40 & 3 & 20.00 \\
\hline
\end{tabular}

In the present study, the deposit of $\operatorname{IgG}$ and $\operatorname{IgM}$ in kidneys was assessed by immunohistochemical technique. The results showed subendothelial granular deposits in glomerular capillaries. IgM reactions were more intense and marking of mesangial cells and interstitial inflammatory infiltrate were rarely seen. Differently from the $\operatorname{IgG}$ reactions that were weaker in the renal glomeruli, the presence of mesangial cells with fluorescent staining in the cytoplasm was more frequent, and the inflammatory infiltrate was frequently stained in these kidney sections. As to the localization of granules, reaction intensity, and pattern of distribution, the results corroborate those found in renal immunohistochemical assay of 26 dogs with naturally acquired Leishmania chagasi infection (Costa et al., 2003).

This study also detected IgM in all cases and always with a more intense reaction than IgG. The deposits of immunoglobulins, IgG as well as IgM, showed a granular appearance and were located on the glomerular capillary walls more frequently than in the mesangium. Similar findings were reported in animals with visceral leishmaniasis. An investigation of 34 dogs with naturally acquired Leishmania infantum infection revealed granular deposits of $\operatorname{IgG}, \operatorname{IgM}$, and $\mathrm{C}_{3}$ in the mesangium, as well as on the glomerular capillary walls (Poli et al., 1991). Results were similar to those reported from other authors who found immune complex deposits in basement membrane from eleven dogs identified as carriers of visceral leishmaniasis (Benderitter et al., 1998).

In the study of golden hamsters infected with Leishmania donovani, IgG granular deposits were detected in glomeruli (basal lamina and mesangial matrix), blood vessels and in some tubules, using an immunofluorescence technique (Agu et al., 1981). On the other hand, a study of nephropathies in dogs with leishmaniasis using the peroxidase-antiperoxidase (PAP) technique showed deposits of $\operatorname{IgG}, \operatorname{IgM}$, and IgA in the subendothelium and mesangial matrix (Nieto et al., 1992).

The mechanism of interstitial nephritis in VL is not yet well known. The finding of interstitial immunoglobulin and complement deposits seen in the immunofluorescence study in one of 50 evaluated patients supports the theory of an immunological mechanism related to parasitic infection (Dutra et al., 1985).

Considering these aspects, interstitial nephritis as well as glomerulonephritis could be the result of immunologically mediated damage. The histological findings of immunoglobulin deposits in the mesangial matrix and in basement membranes suggest that pathology of kidney disease in Leishmania infections would have and immunologic origin (Poli et al., 1991).

In conclusion, in canine visceral leishmaniasis, the IgM reactions were more intense than those of $\mathrm{IgG}$, and were characterized by distribution of subendothelial granules in glomerular capillaries; in the $\operatorname{IgG}$ and $\operatorname{IgM}$ immunohistochemical reactions, the subendothelial granules in the glomeruli presented varying patterns of distribution: global, segmental, diffuse, or focal; the $\operatorname{IgM}$ immunohistochemical reactions in symptomatic positive dogs presented more intense subendothelial deposits then those presented by the asymptomatic dogs. 


\section{ACKNOWLEDGMENTS}

The authors wish to thank FAPESP, for financial support; the Zoonosis Control Center in Teresina, Piauí State, for animal donation; and Maria Inês Yamazaki de Campos and Francisca de Assis Ardisson, for preparation of histological sections.

\section{REFERENCES}

AGU, W.E.; FARRELL, J.P.; SOULSBY, E.J.L. Proliferative glomerulonephritis in experimental Leishmania donovani infection of the golden hamster. Comp. Immunol. Microbiol. Infec. Dis., v.4, p.353-368, 1981.

BENDERITTER, T.H.; CASANOVA, P.; NASHKIDACHVILI, L. et al. Glomerulonephritis in dogs with canine leishmaniasis. Ann. Trop. Med. Parasitol., v.82, p.335-341, 1998.

COSTA, F.A.L.; GOTO, H.; SALDANHA, L.C.B. et al. Histopathologic patterns of nephropathy in naturally acquired canine visceral leishmaniasis. Vet. Pathol., v.40, p.677-684, 2003.

DE BRITO, T.; HOSHINO-SHIMIZU, S.; AMATO NETO, $\mathrm{V}$. et al. Glomerular involvement in human kala-azar. Am. J. Trop. Med. Hyg., v.24, p.9-18, 1975.
DUTRA, M.; MARTINELLI, R.; CARVALHO, E.M. et al. Renal involvement in visceral leishmaniasis. Am. J. Kidney Dis., v.6, p.22-27, 1985.

GRAUER, G.F. Glomerulonephritis. Semin. Vet. Med. Surg. (Small Anim.), v.7, p.187-197, 1992.

NIETO, C.G.; NAVARRETE, I.; HABELA, M.A. et al. Pathological changes in kidneys of dogs with natural Leishmania infection. Vet. Parasitol., v.45, p.33-47, 1992.

POLI, A.; ABRAMO, F.; MANCIANTI, F. et al. Renal involvement in canine leishmaniasis: a light-microscopic, immunohistochemical and electron-microscopic study. Nephron, v.57, p.444-452, 1991.

SARTORI, A.; OLIVEIRA, A.V.; ROQUEBARREIRA, M.C. et al. Immune complex glomerulonephritis in experimental kala-azar. Parasitol. Immunol., v.9, p.93-103, 1987.

ZATZ, R.; FUJIHARA, C.K. Mecanismos de progressão das glomerulopatias progressivas. In: SOARES, V.; ALVES, M.A.R.; BARROS, R.T. (Ed.). Glomerulopatias: patogenia, clínica e tratamento. São Paulo: Sarvier, 1999. p.250-260. 